\title{
Marfan Syndrome: Defective Synthesis, Secretion, and Extracellular Matrix Formation of Fibrillin by Cultured Dermal Fibroblasts
}

\author{
Dianna McGookey Milewicz," Reed E. Pyeritz," E. Stanley Crawford," and Peter H. Byers" \\ Departments of ${ }^{* \|}$ Medicine and ${ }^{\| P a t h o l o g y, ~ a n d ~}{ }^{* \|}$ Center for Inherited Disease, University of Washington, Seattle, Washington 98195 ; \\ ${ }^{\ddagger}$ Department of Medicine, Johns Hopkins University, Baltimore, Maryland 21205; and \\ ${ }^{\S}$ Department of Surgery, Methodist Hospital, Houston, Texas 77030
}

\begin{abstract}
We studied the synthesis, secretion, and aggregation into the extracellular matrix of fibrillin by dermal fibroblasts from 26 probands with the Marfan syndrome. Cells from seven probands synthesized approximately half the normal amount of fibrillin when compared with intrafamilial or unrelated controls. Cells from an additional seven probands synthesized a normal amount of fibrillin but secreted the protein less efficiently than control cells. Cells from a further eight probands synthesized and secreted normal amounts of fibrillin but the protein was poorly incorporated into extracellular matrix. Cells from the remaining four probands were indistinguishable from control cells in their synthesis and processing of fibrillin. Cells from 18 family members of 10 of the probands were also studied. Cells from affected individuals in the same family had the same biochemical defect and those from unaffected family members were indistinguishable from controls. These results indicate that mutations in the gene that encodes fibrillin are responsible for the Marfan syndrome in the majority of individuals (confirming recent immunohistochemical and genetic linkage studies) and that a variety of mutations can produce the phenotype associated with the syndrome. (J. Clin. Invest. 1992. 89:79-86.) Key words: extracellular matrix • fibrillin • Marfan syndrome $\bullet$ microfibrils $\bullet$ secretion
\end{abstract}

\section{Introduction}

The Marfan syndrome is a dominantly inherited disorder characterized by cardiovascular, ocular, and skeletal abnormalities. Abnormal skeletal findings include scoliosis, joint laxity, arachnodactyly, anterior chest deformities, and tall stature $(1,2)$. The ocular manifestations of the disease include lens dislocation, myopia, and retinal detachment. The major cardiovascular complications of ascending aortic dilatation and dissection often lead to premature death in the absence of treatment $(3,4)$.

This study was presented in part at the 41 st Meeting of the American Society of Human Genetics, Cincinnati, OH, 16-20 October 1990 and published in abstract form (1990. Am. J. Hum. Genet. 47:A67).

Dr. Milewicz's current address is Division of Medical Genetics, Department of Internal Medicine, University of Texas Medical School at Houston, P.O. Box 20708, Houston, TX 77225.

Address reprint requests to Dr. Byers, Department of Pathology, SM-30, University of Washington, Seattle, WA 98195.

Received for publication 21 November 1990 and in revised form 3 September 1991.

J. Clin. Invest.

(C) The American Society for Clinical Investigation, Inc.

$0021-9738 / 92 / 01 / 0079 / 08 \$ 2.00$

Volume 89, January 1992, 79-86
To explain the pleiotropic manifestations of the Marfan syndrome, a candidate gene product must be expressed in or affect many tissues including the proximal aorta and the zonules of the eye. Microfibrils are 10-12-nm fibers found in diverse tissues and, pertinent to the pathogenesis of the Marfan syndrome, are the major structural component of zonular fibers and are associated with elastic fibers in the aorta and other tissues $(5,6)$. Fibrillin is a large $(350 \mathrm{kD})$ glycoprotein that is part of the microfibrils $(7)$. Godfrey et al. $(8,9)$ and Hollister et al. (10) recently showed that monoclonal antibodies to fibrillin stain skin and extracellular matrix of cultured fibroblasts from individuals with the Marfan syndrome less intensely than those from controls. The localization of fibrillin to many tissues affected by the Marfan syndrome (7) coupled with evidence of abnormal fibrillin matrix deposition by Marfan cells and tissues suggest that fibrillin synthesis or structure may be defective in the Marfan syndrome.

A locus for mutations that produce the Marfan syndrome was recently mapped to the long arm of chromosome 15 (15q21) using random chromosomal probes (11-13). More recent studies indicate that the gene that encodes one species of fibrillin is located on chromosome 15 at the site identified by random markers to be linked to the Marfan syndrome (14), that the Marfan phenotype is linked to polymorphisms in the fibrillin gene on chromosome 15 (14), and that point mutations in that gene have been identified in two individuals with the Marfan syndrome (15).

To determine if fibrillin production was abnormal in cells from individuals with the Marfan syndrome, we studied the synthesis, secretion, and extracellular matrix incorporation of fibrillin by dermal fibroblasts from 26 affected probands. Cells from 22 of these 26 probands had defects in the amount of fibrillin synthesized, in the efficiency of secretion of fibrillin or in the incorporation of fibrillin into the extracellular matrix. These results imply that fibrillin is the most likely candidate protein for defects that explain the Marfan phenotype. Further, they suggest that different mutations in the gene that encodes fibrillin can produce a similar phenotype.

\section{Methods}

Clinical characteristics of the study population. The diagnosis of all individuals with the Marfan syndrome was based on diagnostic criteria previously established (2) (Table I). Individuals and family members with the Marfan syndrome were identified in several ways. First, some affected individuals (six probands) were identified as part of evaluation at the University of Washington Medical Genetics Clinic where they were seen and evaluated by Dr. Milewicz and/or Dr. Byers. A second group (seven probands) were identified because they were referred to Methodist Hospital, Houston, Texas (Dr. Crawford) for aortic aneurysm repair. The third group consisted of families (five probands) from Johns Hopkins Hospital whose cells were studied in a single-blind protocol (Dr. Pyeritz). In this group biopsies were identified by coded 
Table I. Clinical Features of Individuals with the Marfan Syndrome and Relationship to Fibrillin Production

\begin{tabular}{ccccccc}
\hline Patient & Age & M/F & $\begin{array}{l}\text { Family } \\
\text { history }\end{array}$ & Eyes & Skeleton ${ }^{*}$ & Cardiac $^{*}$ \\
\hline$y r$ & & &
\end{tabular}

I. Decreased synthesis of fibrillin

\begin{tabular}{|c|c|c|c|c|c|c|c|}
\hline $88-324$ & 30 & $\mathbf{M}$ & No & Ectopia & $A, P, S$ & MVP, An(S) & $>97$ \\
\hline $89-123^{11}$ & 5 & $\mathbf{F}$ & Yes & Myopia & $A, P, S$ & MVP & $>97$ \\
\hline $89-160$ & 59 & $\mathbf{M}$ & Yes & Myopia & $\mathrm{A}, \mathrm{P}$ & An & $>97$ \\
\hline $89-162$ & 28 & $\mathbf{M}$ & Yes & Myopia & $\mathrm{A}, \mathrm{S}$ & MVP & $>97$ \\
\hline $89-170^{11}$ & 24 & $F$ & Yes & Myopia & $A, S$ & MVP, An(S) & $>97$ \\
\hline $89-232$ & 11 & $\mathbf{F}$ & Yes & Ectopia & A & MVP & $>97$ \\
\hline $89-112$ & 18 & $\mathbf{M}$ & No & Ectopia & $A, P, S$ & An & $>97$ \\
\hline $86-038$ & 54 & $\mathbf{M}$ & Yes & Ectopia & $\mathrm{A}, \mathrm{S}$ & $\operatorname{An}(S)$ & $>90$ \\
\hline $90-161$ & 28 & $\mathbf{M}$ & Yes & Myopia & $\mathbf{P}$ & MVP, An & $>97$ \\
\hline $90-212$ & 35 & $\mathbf{M}$ & No & Ectopia & $\mathbf{P}$ & An & $>97$ \\
\hline
\end{tabular}

II. Normal synthesis, defective secretion (defect in matrix formation)

\begin{tabular}{|c|c|c|c|c|c|c|c|}
\hline 88-006 & 3 & $\mathbf{M}$ & No & Ectopia & $A, P, S$ & MVP(S), An & $>97$ \\
\hline 89-195 & $\cdot 4$ & $\mathbf{M}$ & No & Ectopia & $A, P, S$ & MVP, An(S) & $>97$ \\
\hline $89-178$ & $\mathrm{NB}^{1}$ & $\mathbf{M}$ & No & Ectopia & $A, P, S$ & ** & $\mathrm{NA}^{\ddagger}$ \\
\hline $88-030$ & 3 & $\mathrm{~F}$ & Yes & Normal & $\mathrm{P}, \mathrm{S}$ & MVP, An & 75 \\
\hline $88-031^{11}$ & 10 & $\mathbf{M}$ & Yes & Normal & $\mathrm{A}, \mathrm{P}$ & MVP, An & 97 \\
\hline $87-194$ & 1 & $\mathbf{F}$ & No & Myopia & $A, P, S$ & MVP, An & 90 \\
\hline 86-039 & 42 & $F$ & Yes & Ectopia & A & $\operatorname{An}(\mathbf{S})$ & $>97$ \\
\hline 90-002 & 6 & $\mathbf{M}$ & No & Ectopia & $A, P, S$ & MVP(S), An & $>97$ \\
\hline
\end{tabular}

III. Normal synthesis, normal secretion, defective matrix formation

\begin{tabular}{|c|c|c|c|c|c|c|c|}
\hline 89-093 & 1 & $\mathbf{M}$ & No & Ectopia & $A, S$ & MVP, An & $>97$ \\
\hline $86-084$ & 36 & $\mathbf{M}$ & NA & NA & $A, P, S$ & $\operatorname{An}(\mathbf{S})$ & $>97$ \\
\hline $86-088$ & 54 & $F$ & NA & NA & A & $A n(S)$ & $>97$ \\
\hline $86-085$ & 35 & $\mathbf{M}$ & NA & NA & NA & $\operatorname{An}(S)$ & NA \\
\hline $89-391$ & 37 & $\mathbf{M}$ & No & Ectopia & $A, P$ & $A n(S)$ & 70 \\
\hline $90-194$ & 55 & $\mathbf{M}$ & Yes & Myopia & $A, S, P$ & An & $>97$ \\
\hline $90-196$ & 33 & $\mathbf{M}$ & Yes & Myopia & & $A n(S)$ & $>97$ \\
\hline $90-179$ & 27 & $F$ & No & Myopia & $\mathbf{P}$ & $A n(S)$ & 75 \\
\hline
\end{tabular}

IV. No abnormality found

$\begin{array}{llllllll}86-042 & \text { NA } & \text { M } & \text { Yes } & \text { NA } & \text { A, P } & \text { An(S) } \\ 89-182 & 24 & \text { M } & \text { No } & \text { Ectopia } & \text { A, P, S } & \text { MVP, An(S) } \\ 86-072 & 15 & \text { F } & \text { Yes } & \text { NA } & \text { S } & \text { An(S) } \\ 90-068 & 33 & \text { M } & \text { No } & \text { Myopia } & \text { P } & \text { An } & \text { NA }\end{array}$

* A, arachnotdactyly; P, pectus deformities; S, scoliosis. ${ }^{\ddagger}$ MVP, mitral valve prolapse; An, aneurysm; (S), surgery. ${ }^{\S}$ Percentile for height based on age. "Affected family members are immediately preceding. 'NB, newborn. ** Died in the immediate perinatal period of cardiac complications; details not available. \#NA, not available. In group I, 88-324 is the father of 89-123 and 89-160 is the father of 89-162 and 89-170; in group II, 88-030 and 88-031 are siblings.

number and the code was broken after all family members had been studied. The remaining probands were identified by geneticists at a variety of centers and skin biopsy specimens were provided for study.

Preparation and electrophoretic analysis of fibrillin. Dermal fibroblasts were obtained from 26 probands with the Marfan syndrome, five affected family members, 13 unaffected family members from 10 families, and five nonfamilial controls, all with appropriate consent. Biopsy samples were explanted and fibroblasts were maintained in culture as previously described (16). To radiolabel synthesized proteins, 250,000 dermal fibroblasts were plated in 35-mm dishes (Corning Glass, Inc., Corning, NY), allowed to attach and spread for $72 \mathrm{~h}$ in Dulbecco-Vogt modified Eagle' medium (DME) supplemented with $10 \%$ fetal calf serum (Irvine Scientific, Santa Ana, CA). The medium was replaced with DME lacking fetal calf serum and cysteine but supplemented with sodium ascorbate $(50 \mathrm{~g} / \mathrm{ml})$ and incubated for $2 \mathrm{~h}$. Then the cells were labeled with ${ }^{35}$ S $]$ cysteine (ICN Biomedicals, Inc., Costa Mesa, CA; $2,400 \mathrm{mCi} / \mathrm{mM}$ ). Medium was collected and the cell layer was washed in DME and then harvested in $50 \mathrm{mM}$ Tris-HCl, pH 8.0, $1 \% \mathrm{NP} 40$, and $1 \mathrm{mM}$ phenylmethylsulfonyl fluoride. After the cell lysate was aspirated from the dish, the material remaining on the dish was scraped into the same buffer with a rubber policeman and the insoluble proteins were collected by centrifugation at $10,000 \mathrm{~g}$ for $5 \mathrm{~min}$ at $4^{\circ} \mathrm{C}$. Proteins were dissolved in sample buffer containing SDS and $\beta$-mercaptoethanol (17), separated by electrophoresis in $4 \%$ acrylamide slab 
gels containing sodium dodecyl sulfate, and localized by radioautography using preflashed film exposed in the linear range. For continuous labeling, cells were incubated in the presence of $\left[{ }^{35} \mathrm{~S}\right]$ cysteine $(50 \mu \mathrm{Ci}$ in $0.7 \mathrm{ml}$ ) in cysteine-free medium supplemented with ascorbate, for $20 \mathrm{~h}$. For pulse-chase experiments, after preincubation in cysteine-free media, cells were pulsed for 30 min with $\left[{ }^{35} \mathrm{~S}\right]$ cysteine $(50 \mu \mathrm{Ci}$ in $0.15 \mathrm{ml})$ in cysteine-free medium supplemented with ascorbate. The medium was then removed, the cells were washed extensively with DME and then incubated in the presence of DME supplemented with $50 \mathrm{~g} / \mathrm{ml}$ ascorbic acid for up to $20 \mathrm{~h}$. The medium, cell lysate, and cell layer were then harvested as described above and proteins were separated by sodium dodecyl sulfate polyacrylamide gel electrophoresis. Radioactivity in fibrillin and in an anonymous protein migrating just above fibrillin (see Fig. 1) was quantitated by scanning densitometry of preflashed radioautographic films exposed in the linear range.

Immunoprecipitation. Fibrillin was identified in aliquots of medium by immunoprecipitation with a previously characterized monoclonal antibody (19); the antigen-antibody complex was precipitated

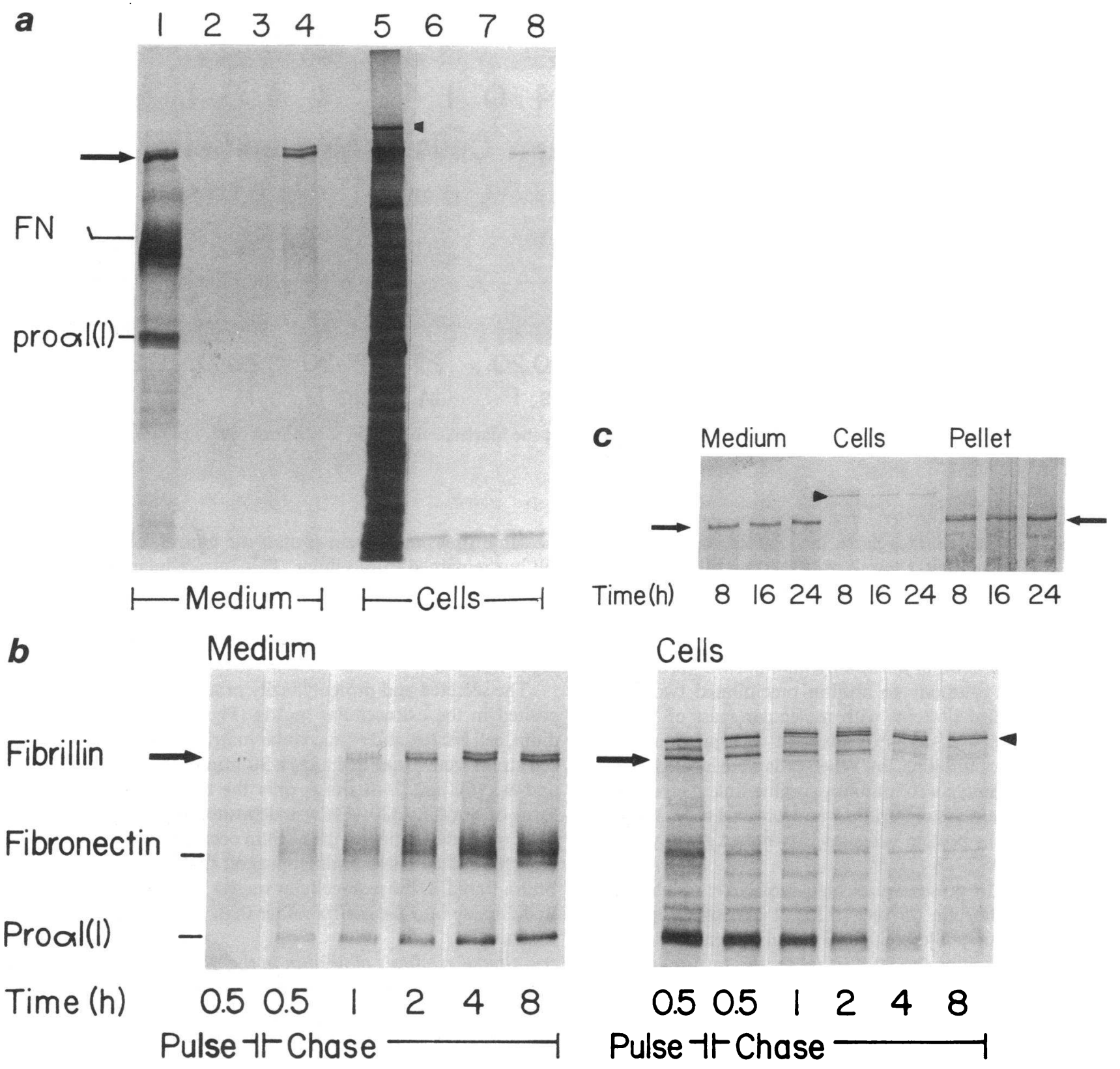

Figure 1. Synthesis and secretion of fibrillin by cultured fibroblasts. (a) Identification of fibrillin. Cells were pulsed for $2 \mathrm{~h}$ with [ ${ }^{35}$ S]cysteine after which the medium and intracellular proteins were harvested separately and fibrillin was isolated by immunoprecipitation. Lanes 1 and 5 contain total medium and cell proteins, respectively. The precipitates in lanes 2 and 6,3 and 7 , and 4 and 8 used 0,10 , and $100 \mu l$, respectively, of the antibody. Fibrillin appears as the doublet (arrow) and an anonymous intracellular protein is identified by the arrowhead. (b) Kinetics of secretion of fibrillin by cultured fibroblasts. Cells were incubated for $30 \mathrm{~min}$ in the presence of $\left[{ }^{35} \mathrm{~S}\right]$ cysteine and then chased for up to $8 \mathrm{~h}$ in the absence of label. Fibrillin (arrow) is synthesized as a precursor protein. Secretion begins within $1 \mathrm{~h}$ and virtually all fibrillin is secreted by $8 \mathrm{~h}$. The protein is secreted as the precursor molecule and converted by proteolysis to a slightly smaller product during the period of incubation. An unrelated, higher molecular mass intracellular protein (arrowhead) is synthesized and processed within the cell but not secreted. (c) Deposition of fibrillin into the extracellular matrix. Cells were incubated for $30 \mathrm{~min}$ in the presence of $\left[{ }^{35} \mathrm{~S}\right]$ cysteine and then chased for up to $24 \mathrm{~h}$. The medium, cell lysates, and insoluble matrix protein were collected at 8,16 , and $24 \mathrm{~h}$ and analyzed by SDS-PAGE. By $8 \mathrm{~h}$ the amount of fibrillin in the matrix has stabilized suggesting that there is little deposition of fibrillin from the medium. 
Figure 2. Decreased synthesis of fibrillin by cells from individuals with the Marfan syndrome. (a) Cells were incubated with $\left[{ }^{35} \mathrm{~S}\right]-$ cysteine for $30 \mathrm{~min}$ and then chased for 1 and $4 \mathrm{~h}$. At the end of the pulse, the cells from the Marfan cell strain (patient 88-324) have synthesized less fibrillin than the cells from the unaffected family member. The rate of secretion is comparable. (b) Cells were incubated for $30 \mathrm{~min}$ with $\left[{ }^{35} \mathrm{~S}\right]$ cysteine for $30 \mathrm{~min}$ and then chased for $20 \mathrm{~h}$, at which time medium $(M)$, intracellular proteins (cells), and proteins in the matrix $(P)$ were harvested. The cells from the affected individual $(B)$ (patient 89232) synthesize less fibrillin than those from the two unaffected siblings $(A$ and $C)$. The efficiency of secretion is similar in the cell strains but the amount of fibrillin in the matrix is less in the Marfan cell strain, reflecting the decrease in synthesis. (c) Cells were incubated with $\left[{ }^{35} \mathrm{~S}\right]$ cysteine for $30 \mathrm{~min}$ and then chased for 2 and $8 \mathrm{~h}$ in the absence of label after which cells and medium were harvested and analysed by SDS-PAGE. Cells in panels $A$ (patient 89-160) and $C$ (patient 89-162) are derived from affected individuals in one family and those in $B$ and $D$ from unaffected family members in the same family. When compared to the large

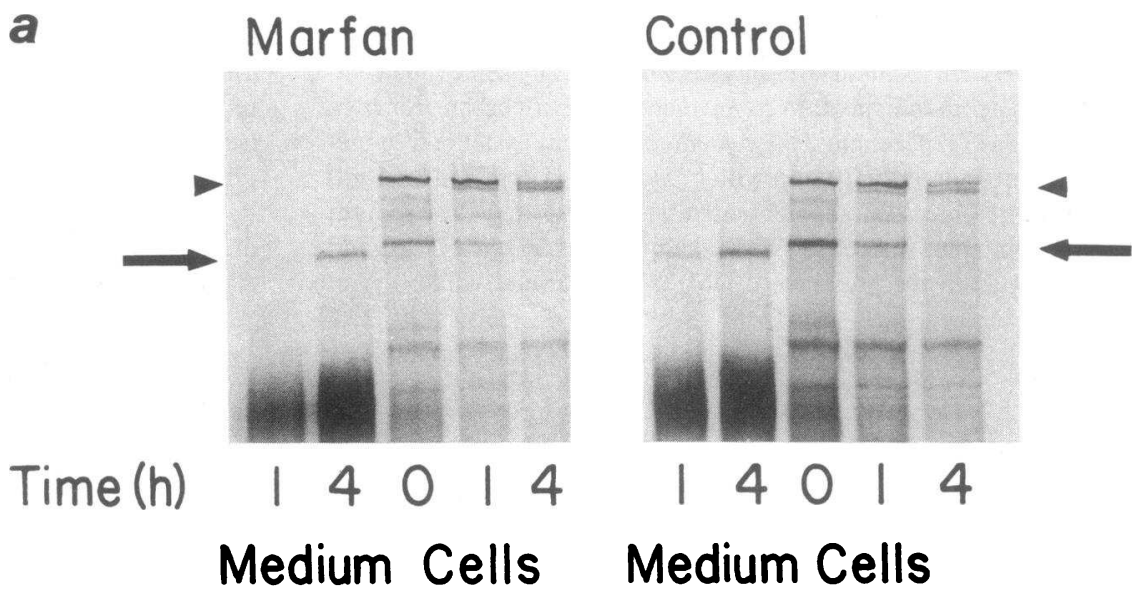
intracellular protein (arrowhead), there is less fibrillin (arrow) synthesized in the Marfan cells than in the control cells. The rate of secretion from the cells is comparable.

with Protein G Sepharose (Pharmacia, Inc., Piscataway, NJ) as described (18). The monoclonal antibody was a generous gift of Dr. Lynn Sakai, Shriners Hospital, Portland, OR.

\section{Results}

Synthesis and secretion of fibrillin by human skin fibroblasts. The monoclonal antibody to fibrillin precipitated two large $\left[{ }^{35}\right.$ S]cysteine-labeled proteins with molecular mass of $\sim 350$ and $320 \mathrm{kD}$ (Fig. 1 a, arrow), consistent with previous estimates of the size of fibrillin (20). When cells were labeled in the presence of tunicamycin to inhibit aspargine-linked glycosylation, the apparent mass of fibrillin was decreased to $\sim 320 \mathrm{kD}$ confirming that the protein had sites of $\mathrm{N}$-linked glycosylation (data not shown).

After a 30-min pulse several high molecular weight proteins, including fibrillin (arrows in Fig. 1 and other figures), were labeled with $\left[{ }^{35}\right.$ S]cysteine. Although intensely labeled with $\left[{ }^{35}\right.$ S cysteine after the 30 -min pulse, the intracellular fibrillin decreased with time and appeared in the medium. Most fibrillin was secreted after $4 \mathrm{~h}$. Fibrillin secreted into the medium appeared as a doublet, the upper member of which comigrated with the intracellular protein and the lower member of which was a form $\sim 30 \mathrm{kD}$ smaller (Fig. $1 b$ ). In some experiments the transfer of label from the larger to the small protein was apparent. These results suggest that fibrillin is synthesized as a precursor protein (profibrillin), secreted from the cell, and processed extracellularly to a lower molecular weight product (fibrillin). The rate of conversion of the precursor to final product varied among control cell strains but was generally complete by $20 \mathrm{~h}$. In others, at the end of a shorter period label was apparent only in the smaller protein (see, for example, Fig. $1 c$ ). An anonymous protein larger than fibrillin was synthesized at the same time, underwent proteolytic conversion within the cell but remained intracellular. This intracellular protein (arrowheads in all figures) was used as an internal standard to compare the amount of fibrillin synthesized in different cell strains because of its proximity to and similar intensity of labeling to fibrillin.

The secreted and proteolytically processed fibrillin was deposited in the extracellular matrix (Fig. $1 c$ ). When the medium, cell lysates, and extracellular matrix proteins of a control cell strain were examined after a 30 -min pulse of $\left[{ }^{35} \mathrm{~S}\right]$ cysteine and 8-, 16-, and 24-h chase, only the lower molecular mass form of fibrillin $(320 \mathrm{kD})$ was deposited in the matrix, with most of the deposition of the fibrillin occurring in the initial $8 \mathrm{~h}$ after the pulse. These findings suggest that the majority of fibrillin found in the extracellular matrix is secreted and deposited directly into the matrix rather than precipitating from the medium.

Altered synthesis of fibrillin in the Marfan syndrome. Skin fibroblasts from seven probands and additional members of two families synthesized approximately half the normal amount of fibrillin (Fig. 2) when compared with control cells or those from nonaffected family members. Fig. $2 a$ shows that the Marfan cell strain incorporated approximately half the amount of $\left[{ }^{35} \mathrm{~S}\right]$ cysteine into fibrillin (arrows) when compared with cells from an unaffected family member, using the larger intracellular protein (arrowheads) as a standard. After $4 \mathrm{~h}$ of chase, the majority of the fibrillin was secreted and processed to the lower molecular mass form in these two cell strains. The reduced amount of fibrillin in the medium of the Marfan cell strain at $4 \mathrm{~h}$ reflected the diminished synthesis. Fig. 2, b and $c$, shows results from cells from members of two other families in which the cells from affected individuals synthesized approxi- 


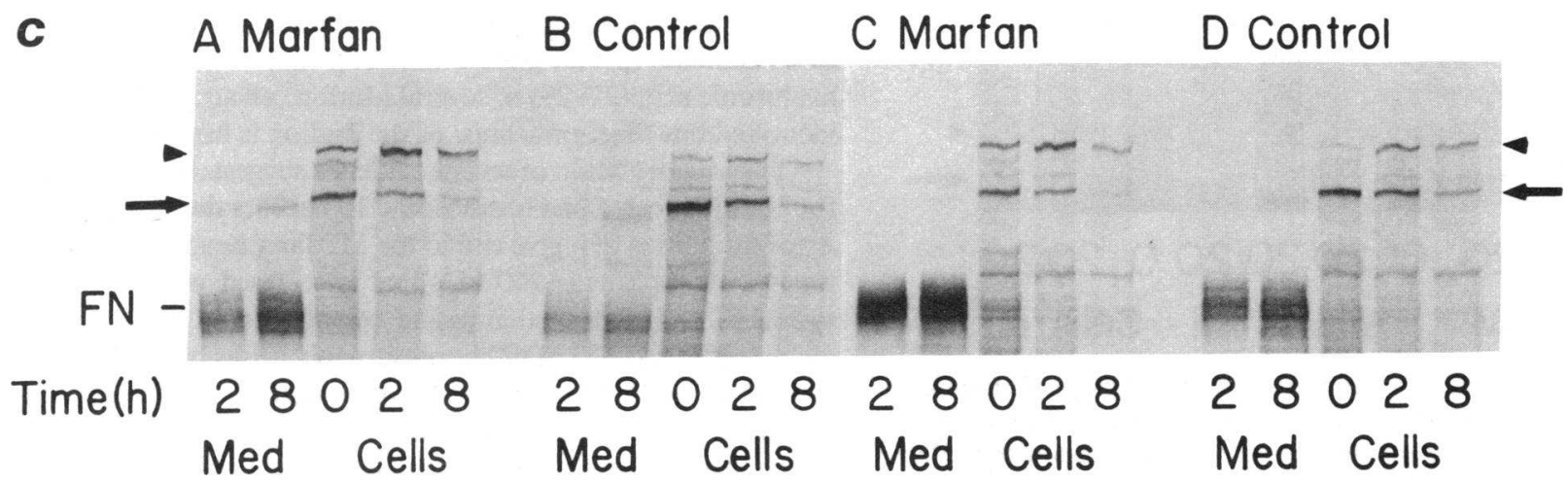

Figure 2 (Continued)

mately half the amount of fibrillin as those from unaffected family members. Radiolabel in fibrillin was compared to that in the anonymous high molecular mass protein (arrowheads) by scanning densitometry of autoradiograms (data not shown). Cells from each individual in this group incorporated $~ 50 \%$ of the label into fibrillin as the controls when standardized to the label incorporated into the standard protein.

Altered secretion of fibrillin in the Marfan syndrome. Cells from probands in seven families plus an affected relative in one family synthesized normal amounts of fibrillin but the efficiency of secretion of fibrillin was decreased (Fig. 3). Fig. $3 a$ demonstrates a pulse/chase experiment with cells from a proband and an age-matched control. After a 30-min pulse of $\left[{ }^{35} \mathrm{~S}\right]$ cysteine the two cell strains synthesized similar amounts of fibrillin judging by label incorporation. By $8 \mathrm{~h}$ of chase the control cells had secreted all the fibrillin from the cell, whereas the cells from the affected individual still contained intracellular fibrillin. In another example (Fig. $3 b$ ), cells from a normal woman and her two affected children (the affected father had died at age $32 \mathrm{yr}$ from aortic dissection and cells were not available) were incubated with $\left.{ }^{35} S\right]$ cysteine for $20 \mathrm{~h}$ and the medium and cell layer proteins were examined by SDS-PAGE. Cells from both children, but not from the mother, contained readily detectable amounts of fibrillin. The fibrillin in the cell layer was protected when the cells were removed from the dish with trypsin before lysis, confirming the intracellular location of the protein.

Altered incorporation of fibrillin into the extracellular matrix. Cells from a third group of affected individuals made normal amounts of fibrillin, secreted it efficiently, but were unable to deposit the fibrillin into the extracellular matrix. To study fibrillin deposition in the cell-associated matrix, cells were pulsed with $\left.{ }^{35} \mathrm{~S}\right]$ cysteine for $30 \mathrm{~min}$ and then incubated for 20 $\mathrm{h}$ in the absence of label. Proteins in the medium, cell lysate and extracellular matrix were then examined by SDS-PAGE. In control cells after the 20-h chase, only the lower molecular mass form of fibrillin was present in the medium from control cells, there was no fibrillin in the cell lysates, and the insoluble protein remaining on the dish after the cells were lysed contained a protein that comigrated with the processed form of fibrillin found in the medium. Cells from eight probands, plus an additional affected family member of one proband, synthesized normal amounts of fibrillin and secreted it at a normal rate but failed to deposit fibrillin in the extracellular matrix (see Fig. 4 for an example). Although only eight cell strains demonstrated this abnormality alone, most of those from the second group (defective secretion) were unable to deposit fibrillin into the extracellular matrix effectively.

Four cell strains from individuals with the Marfan syndrome had no identifiable defect in fibrillin synthesis, secretion, or deposition in the extracellular matrix and were not distinguishable from control cell strains.

Clinical-biochemical correlation. The majority of individuals studied had most of the cardinal features of the Marfan syndrome, making biochemical-clinical correlations difficult (Table I). Five of the seven probands in group II (defective secretion) represented more severe phenotypes. These five individuals were the first affected family members (presumably representing new mutations at the Marfan locus), were identified at or soon after birth, and either died in the perinatal pe-

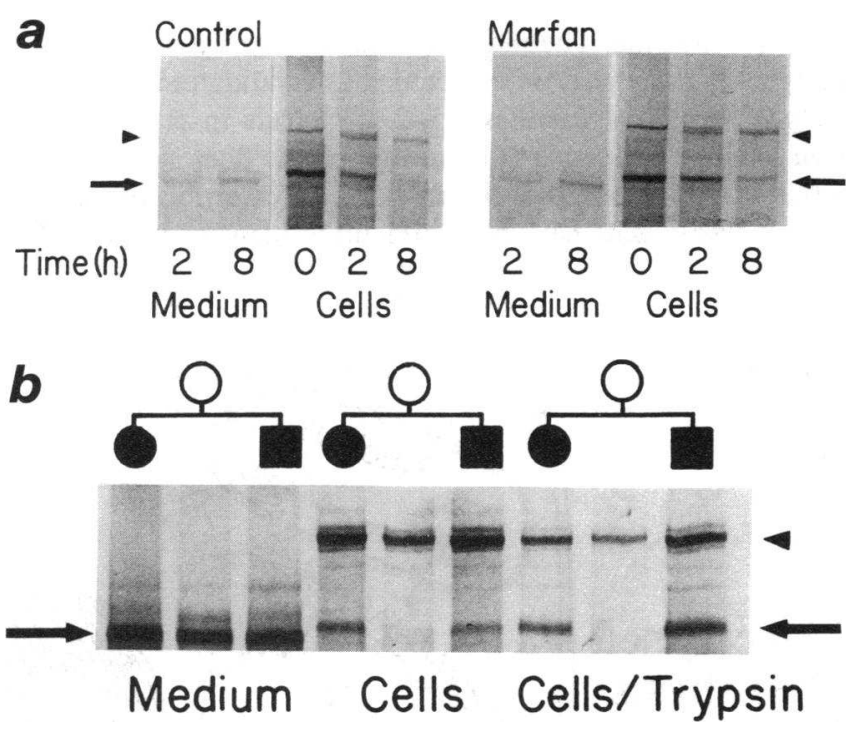

Figure 3. Altered secretion of fibrillin by cells from individuals with the Marfan syndrome. (a) Cells from a proband (89-178) and an agematched control were incubated with $\left[{ }^{35} \mathrm{~S}\right]$ cysteine for $30 \mathrm{~min}$ and then chased for up to $8 \mathrm{~h}$. Virtually all the profibrillin is chased from the control cells at the end of $8 \mathrm{~h}$ while a substantial amount remains in the cells from the affected child. (b) Cells from an unaffected mother and her two affected children (patients 88-030 and 88-031) were incubated with $\left[{ }^{35}\right.$ S $]$ cysteine for $16 \mathrm{~h}$ and then the cell layer and medium were harvested. Cells from the affected individual contain a substantial amount of profibrillin which is protected from proteolysis by trypsin harvesting of the cells. 


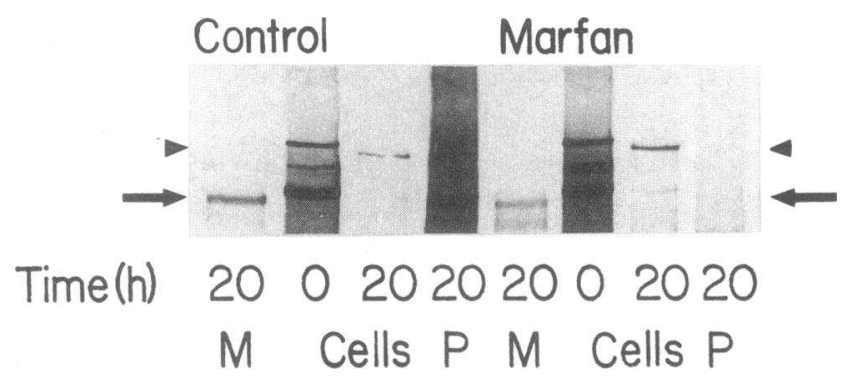

Figure 4. Defective matrix accumulation of fibrillin by cells from an individual with the Marfan syndrome. Cells were incubated with $\left[{ }^{35} \mathrm{~S}\right]$ cysteine for $30 \mathrm{~min}$ and the cells were then chased $20 \mathrm{~h}$ with nonlabeled medium. The amount of fibrillin (arrows) synthesized is similar in the two cell strains, the amount secreted at $20 \mathrm{~h}$ is similar, but only the control cells deposit an appreciable amount of fibrillin in the matrix. The Marfan cells were grown from patient 89-391.

riod or came to surgery for severe cardiac disease (either mitral valve prolapse or aortic aneurysm) at a young age. There was no correlation of molecular abnormality with either the presence or absence of ectopia lentis or the severity of the musculoskeletal aspects of the Marfan syndrome. Individuals in all four groups had been operated on for cardiovascular abnormalities (usually aortic aneurysm formation) but, with the exception of four patients in group II and one patient in group IV, all were adults at the time of surgery.

\section{Discussion}

Until very recently the molecular basis of the Marfan syndrome was not known. Defects in a number of structural proteins had been proposed to explain the clinical features of the Marfan syndrome. The major fibrillar collagen genes, including types I, II and III, were excluded as candidates by linkage analysis in several families (19-24). Defects in elastin have been suspected because of abnormal elastic fiber structure in aortas from affected individuals (25). Polymorphisms in the human elastin gene have been difficult to identify, but studies in a Finnish family using a rare polymorphism excluded elastin as a candidate in that population (26). Increased synthesis of hyaluronic acid (27-29) in several Marfan cell strains has been identified but the significance of the finding is not known.

The accumulation of recent evidence suggests that the gene for fibrillin located on chromosome 15 harbors the vast majority of mutations that give rise to the Marfan phenotype. Fibrillin is a glycoprotein $(350 \mathrm{kD})$ that is secreted within $4 \mathrm{~h}$ of synthesis and deposited into the cell-associated matrix as a smaller protein $(320 \mathrm{kD})$ that presumably arises by proteolytic cleavage (Fig. 5). The deposited protein aggregates, either alone or in conjunction with other proteins, to form both the microfibrillar network associated with elastic fibers and the isolated microfibril network (also referred to as elaunin) present throughout the body (30). With time fibrillin becomes incorporated into fibrillar structures that are poorly soluble and stabilized by inter- and intramolecular disulfide bonds. Microfibrillar protein has been recognized for more than 20 years to be distinct from the protein elastin and is thought to provide the scaffold on which elastin is deposited during development (31). Microfibrillar structures are ubiquitously distributed in the extracellular matrix and are particularly abundant within the aorta, in ligaments, at the sites of epiphyseal growth, and, significantly for the pathogenesis of the Marfan syndrome, constitute a major component of the zonular fibers that maintain the lens in its normal position $(7,32,33)$.

We have identified defects in fibrillin synthesis, secretion, or extracellular matrix formation in fibroblasts from 22 of the 26 probands ( $84 \%$ ) with the Marfan syndrome that we studied (Table I and Fig. 5). One-third of the cell strains synthesized about half the normal amount of fibrillin, consistent with a single null allele or with production of a fibrillin with different electrophoretic mobility that we did not identify. In four families for which we had cells from affected and unaffected relatives, the defect in fibrillin synthesis was seen only in cells from affected individuals and cells from unaffected family members synthesized normal amounts of the protein. The clinical phenotype in affected individuals with this biochemical picture was that of the typical Marfan syndrome, but few patients in this

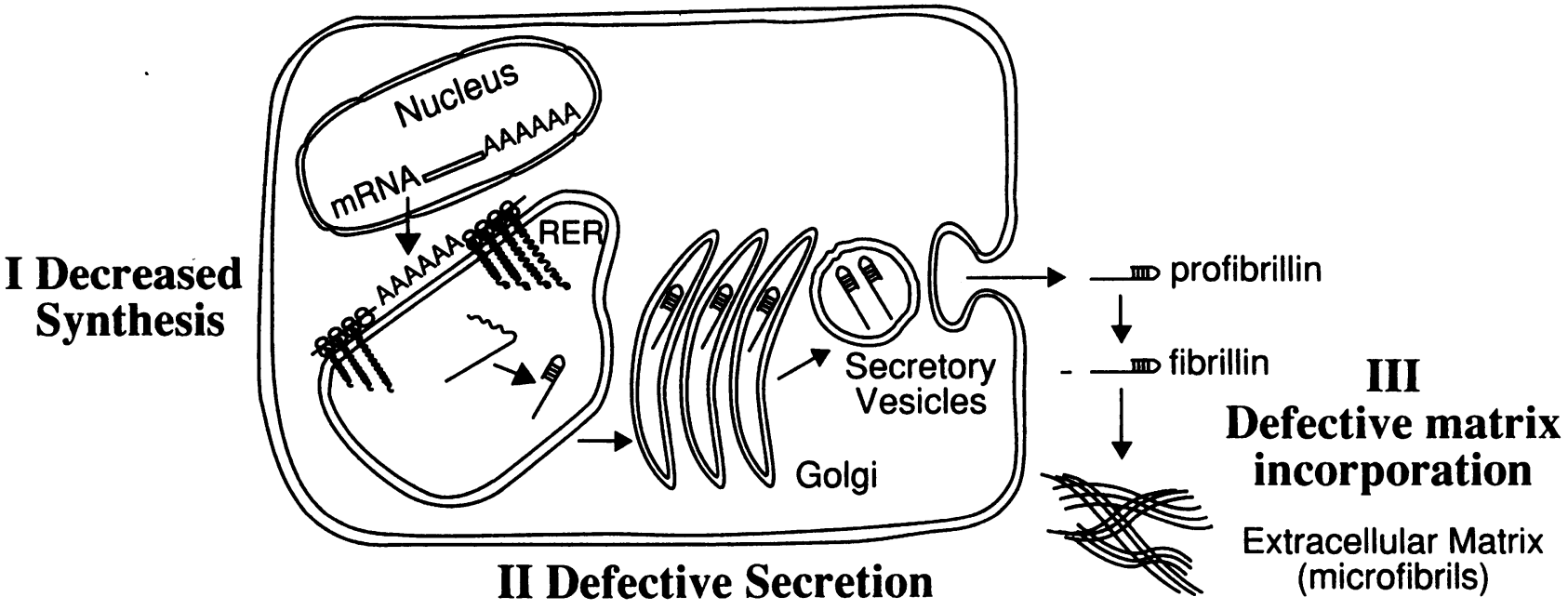

Figure 5. Diagrammatic representation of fibrillin synthesis, secretion, proteolytic conversion, and microfibril formation. The roman numerals indicate the apparent location of defects in synthesis (I), secretion (II), and matrix aggregation (III) of fibrillin in individuals with the Marfan syndrome. 
group had significant aortic disease by age 30 yr. Although the molecular basis of diminished synthesis is not clear it is likely that gene deletions, nonsense mutations in the coding sequence that produce short, unstable molecules, or splicing errors will be most common, in parallel with the defects seen in thalassemias $(34,35)$ and forms of osteogenesis imperfecta $(36,37)$.

An additional third of the cell strains we examined synthesized fibrillin molecules that were slowly secreted from the cell. In most, once secreted the molecules were poorly assimilated into the extracellular matrix. It is likely that these defective molecules slowly attained a folded structure requisite for secretion and thus were retained within the cell for a longer than normal period. Inefficient secretion of proteins with missense point mutations has been documented in several genetic diseases. Abnormal secretion of type I and type III procollagens has been observed in skin fibroblasts from some individuals with osteogenesis imperfecta (38) and Ehlers-Danlos syndrome type IV (39), respectively. In some instances $\alpha_{1}$-antiprotease deficiency $(40,41)$ is the result of mutations in the $\alpha_{1}$-antiprotease gene and at least one mutant allele $(\mathrm{Z})$ leads to inefficient secretion of defective protein.

The defective molecules we identified are retained within the cell for long periods (up to $24 \mathrm{~h}$ ). Once secreted the abnormal molecules appear to disturb multimer formation in the matrix inasmuch as few molecules are found in the pericellular compartment. This group of affected individuals appeared to have the most severe phenotypes and five out of six of the severely affected children we studied had defects in the secretion of fibrillin. The two adults whose cells demonstrated this finding had early onset cardiovascular disease. One dissected his aorta and died in his early 20's while the other came to surgical repair in her early 40's and had other more severely affected relatives.

In members of eight families we identified defects in the ability of cells to assimilate fibrillin into the pericellular matrix. These defects did not alter the amount of fibrillin synthesized or the efficiency of secretion of the molecules synthesized, suggesting that conformational requirements for fibrillogenesis may differ from those for secretion. The clinical phenotypes in these individuals varied from relatively mild (late onset aortic disease) to quite severe (early onset aortic disease).

Finally, in four remaining individuals we were unable to identify a defect in synthesis, secretion, or aggregation of fibrillin in the pericellular matrix.

Our findings help to explain some unusual aspects of previous findings (20-22). In the majority of cell strains and/or skin samples from affected individuals there was a paucity of staining for fibrillin, using a monoclonal antibody to the protein. This result was somewhat unexpected, given the autosomal dominant mode of inheritance of the Marfan phenotype and the expectation that one allele would continue to function in a normal manner. Our findings suggest that alterations in the synthesis or secretion can affect matrix deposition of fibrillin and, in addition, that some mutations affect matrix deposition without affecting either synthesis or secretion. We expect that the cell strains in which there is defective secretion or evidence of altered accumulation into the matrix would be defective in fibrillogenesis and thus stain little with a fibrillin antibody while those deficient only in the amount of fibrillin synthesized might stain normally. Mutations that affect the structure of the protein, regardless of whether they affect secretion, might be expected to have highly deleterious effects on fibrillogenesis because formation of microfibrils must rely on a highly ordered self-assembly process.

The recent publication of partial cDNA sequences for fibrillin $(14,42)$ suggests that the protein (casettes of epidermal growth factor precursor-like units interrupted by motifs found in transforming growth factor- $\beta 1$ binding protein) provides a rich substrate for mutations that could interrupt normal folding (and thus alter secretion and intermolecular interactions), or result in exon skipping events and change protein structure or mRNA stability.

Our findings provide strong support for the hypothesis that fibrillin is the major candidate gene for defects that produce the Marfan phenotype and support the linkage and molecular genetic data already collected (11-14). Furthermore, our data suggest that different types of mutations in the same gene may result in similar phenotypes. In parallel with other genetic disorders, it appears that mutations that affect the structure of the synthesized protein may have more deleterious effects (or early onset of similar findings) than those which affect the expression of the gene.

\section{Acknowledgments}

We thank the families for their cooperation and interest in these studies and the many physicians for providing cells and clinical summaries of their patients. We are indebted to Dr. Lynn Sakai for supplying the fibrillin monoclonal antibody, to Laura Suesserman for growing and maintaining the cells, to Barbara Kovacich for helping to prepare the manuscript, and to Robert Underwood for photographic assistance.

This work was supported in part by grants from the National Institutes of Health (AM-21557, HL-35877, RR-00722, and GM-07454) and the National Marfan Foundation.

\section{References}

1. McKusick, V. A. 1972. Heritable Disorders of Connective Tissue. 4th edition. C. V. Mosby, St. Louis, MO. 61-223.

2. Pyeritz, R. E., and V. A. McKusick. 1979. The Marfan syndrome: diagnosis and management. N. Engl. J. Med. 300:772-777.

3. Murdoch, J. L., B. A. Walker, B. L. Halpern, J. W. Kuzma, and V. A. McKusick. 1972. Life expectancy and causes of death in the Marfan syndrome. N. Engl. J. Med. 286:804-808.

4. Gott, V. L., R. E. Pyeritz, G. J. Magovern, D. E. Cameron, and V. A. McKusick. 1986. Surgical treatment of aneurysms of the ascending aorta in the Marfan syndrome. N. Engl. J. Med. 314:1070-1074.

5. Cleary, E. G., and M. A. Gibson. 1983. Elastin-associated microfibrils and microfibrillar proteins. Int. Rev. Connect. Tissue Res. 10:97-209.

6. Inou, S., and C. P. Leblond. 1986. The microfibrils of connective tissue: I. Ultrastructure. Am. J. Anat. 176:121-138.

7. Sakai, L. Y., D. R. Keene, and E. Engvall. 1986. Fibrillin, a new $350 \mathrm{kD}$ glycoprotein, is a component of extracellular microfibrils. J. Cell Biol. 103:24992509.

8. Godfrey, M., V. Menashe, R. G. Weleber, R. D. Koler, R. H. Bigley, E. Lovrien, J. Zonana, and D. W. Hollister. 1990. Cosegregation of elastin-associated microfibrillar abnormalities with the Marfan phenotype in families. Am. J. Hum. Genet. 46:652-660.

9. Godfrey, M., S. Olson, R. G. Burgio, A. Martini, M. Valli, G. Cetta, H Hori, and D. W. Hollister. 1990. Unilateral microfibrillar abnormalities in a case of asymmetric Marfan syndrome. Am. J. Hum. Genet. 46:661-671.

10. Hollister, D. W., M. Godfrey, L. Y. Sakai, and R. E. Pyeritz. 1990. Immunohistologic abnormalities of the microfibrillar-fiber system in the Marfan syndrome. N. Engl. J. Med. 323:152-159.

11. Kainulainen, K., L. Pulkkinen, A. Savolainen, I. Kaitila, and L. Peltonen. 1990. Location of chromosome 15 of the gene defect causing Marfan syndrome. N. Engl. J. Med. 323:935-939.

12. Dietz, H. C., R. E. Pyeritz, B. D. Hall, R. G. Cadle, A. Hamosh, J. Schwartz, D. A. Meyers, and C. A. Francomano. 1991. The Marfan syndrome locus: confirmation of assignment to chromosome 15 and identification of tightly linked markers at 15q15-q21.3. Genomics. 9:355-361. 
13. Tsipouras, P., M. Sarfarazi, A. Devi, B. Weiffenbach, and M. Boxer. 1991. Marfan syndrome is closely linked to a marker on chromosome 15q1.5q2.1. Proc. Natl. Acad. Sci. USA. 88:4486-4488.

14. Lee, B., M. Godfrey, E. Vitale, H. Hori, M.-G. Mattei, M. Sarfarazi, P. Tsipouras, F. Ramirez, and D. W. Hollister. 1991. Linkage of Marfan syndrome and a phenotypically related disorder to two different fibrillin genes. Nature (Lond.). 352:330-334.

15. Dietz, H. C., G. R. Cutting, R. E. Pyeritz, C. L. Maslen, L. Y. Sakai, G. M. Corson, E. G. Puffenberger, A. Hamosh, E. J. Nanthakumar, S. M. Curristin, et al. 1991. Marfan syndrome caused by a recurrent de novo missense mutation in the fibrillin gene. Nature (Lond.). 352:337-339.

16. Bonadio, J., K. A. Holbrook, R. E. Gelinas, J. Jacob, and P. H. Byers. 1985. Altered triple helical structure of type I procollagen in lethal perinatal osteogenesis imperfecta. J. Biol. Chem. 260:1734-1742.

17. Laemmli, U. K. 1970. Cleavage of structural proteins during assembly of the head of bacteriophage T4. Nature (Lond.). 227:680-685.

18. Gething, M.-J., B. Adler, J.-A. Boose, B. D. Garard, E. L. Madison, D. McGookey, R. S. Meidell, R. M. Roman, and J. Sambrook. 1988. Variants of human tissue-type plasminogen activator that lack specific structural domains of the heavy chain. EMBO (Eur. Mol. Biol. Organ.) J. 7:2731-2740.

19. Tsipouras, P., A. L. Børresen, S. Bamforth, P. S. Harper, and K. Berg. 1986. Marfan syndrome: exclusion of genetic linkage to the COL1A2 gene. Clin. Genet. 30:428-432.

20. Dalgleish, R., J. R. Hawkins, and M. Keston. 1987. Exclusion of the $\alpha 1(\mathrm{I})$ and $\alpha 1$ (III) collagen genes as the mutant loci in a Marfan syndrome family. $J$. Med. Genet. 24:148-151.

21. Ogilvie, D. J., B. P. Wordsworth, L. M. Priestley, R. Dalgleish, J. Schmidtke, B. Zoll, B. C. Sykes. 1987. Segregation of all four major fibrillar collagen genes in the Marfan syndrome. Am. J. Hum. Genet. 41:1071-1082.

22. Schwartz, R. C., S. H. Blanton, C. A. Hyde, T. R. Sottile, Jr., L. Hudgins, M. Sarfarazi, and P. Tsipouras. 1990. Linkage analysis in Marfan syndrome. $J$. Med. Genet. 27:86-90.

23. de Groote, J., P. A. Farndon, M. V. Kilpatrick, A. de Paepe, J. W. Oorthuys, N. C. Nevin, A. H. Child, and F. M. Pope. 1990. Linkage data for Marfan syndrome and markers on chromosomes 1 and 11. J. Med. Genet. 27:82-85.

24. Boileau, C., G. Jondeau, C. Bonaiti, M. Coulon, G. Delorme, O. Dubourg, J.-P. Bourdarias, and C. Junien. 1990. Linkage analysis of five fibrillar collagen loci in a large French Marfan syndrome family. J. Med. Genet. 27:78-81.

25. Perejda, A. J., P. A. Abraham, W. H. Carnes, W. F. Coulson, and J. Uitto. 1985. Marfan's syndrome: structural, biochemical, and mechanical studies of the aortic media. J. Lab. Clin. Med. 106:376-383.

26. Huttunen, K., I. Kaitila, A. Savolainen, A. Palotie, and L. Peltonen. 1989. The linkage analysis with RFLP markers of elastin and type III collagen genes in Finnish Marfan families. Am. J. Med. Genet. 30:244A. (Abstr.)

27. Lambert, S. E., and A. Dorfman. 1973. Synthesis and degradation of hyaluronic acid in the cultured fibroblasts of Marfan's disease. J. Clin. Invest. 52:2428-2433.

28. Matalon, R., and A. Dorfman. 1969. Acid mucopolysaccharides in cultured human fibroblasts. Lancet. 2:838-841.

29. Appel, A., A. L. Horowitz, and A. Dorfman. 1979. Cell-free synthesis of hyaluronic acid in Marfan syndrome. J. Biol. Chem. 254:12199-12203.

30. Cotta-Pereira, G., G. Guerra, and S. Bittencourt-Sampaio. 1976. Oxytalan, elaunin and elastic fibers in the human skin. J. Invest. Dermatol. 66:143-148.

31. Ross, R., and P. Bornstein. 1969. The elastic fiber. I. The separation and partial characterization of its macromolecular components. J. Cell Biol. 40:366381.

32. Streeten, B. W., P. A. Licari, A. A. Marucci, R. M. Dougherty. 1981. Immunohistochemical comparison of ocular zonules and the microfibrils of elastic tissue. Invest. Ophthalmol. Visual Sci. 21:130-135.

33. Raviola, G. 1971. The fine structure of the ciliary zonule and ciliary epithelium: with special regard to the organization and insertion of the zonular fibrils. Invest. Ophthalmol. 10:851-869.

34. Wetherall, D. J., J. B. Clegg, D. R. Higgs, and W. G. Wood. 1989. The hemoglobinopathies. In The Molecular Basis of Inherited Disease. 6th edition. C. R. Scriver, A. L. Beaudet, W. S. Sly, and D. Valle, editors. McGraw-Hill, Inc., New York. 2281-2339.

35. Kazazian, H. H., Jr., C. E. Dowling, P. C. Waber, S. Huang, and W. H. Y. Lo. 1986. The spectrum of $\beta$ thalassemia genes in China and southeast Asia. Blood. 68:964-966.

36. Byers, P. H. 1989. Disorders of collagen biosynthesis and structure. In The Molecular Basis of Inherited Disease. 6th edition. C. R. Scriver, A. L. Beaudet, W. S. Sly, and D. Valle, editors. McGraw-Hill. 2805-2842.

37. Willing, M. C., D. Cohn, B. Starman, K. A. Holbrook, C. Greenberg, and P. H. Byers. 1988. Heterozygosity for a large deletion in the $\alpha 2(\mathrm{I})$ collagen gene has a dramatic effect on type I collagen secretion and produces perinatal lethal osteogenesis imperfecta. J. Biol. Chem. 263:8398-8404.

38. Bonadio, J., and P. H. Byers. 1985. Subtle structural alterations in the chains of type I procollagen produce osteogenesis imperfecta type II. Nature (Lond.). 316:363-366.

39. Holbrook, K. A., and P. H. Byers. 1982. Structural abnormalities in dermal collagen and elastic matrix from the skin of patients with inherited connective tissue disorders. J. Invest. Dermatol. 79:7s-16s.

40. Verbana, K. M., and E. C. Heath. 1986. Biosynthesis, processing and secretion of $\mathrm{M}$ and $\mathrm{Z}$ variant human $\alpha_{1}$-antitrypsin. J. Biol. Chem. 261:99799989.

41. Sifers, R. N., S. Brashears-Macatee, V. J. Kidd, H. Muensch, S. L. C. Woo. 1988. A frameshift mutation results in a truncated $\alpha_{1}$-antitrypsin that is retained within the rough endoplasmic reticulum. J. Biol. Chem. 263:7330-7335.

42. Maslen, C. L., G. M. Corson, B. K. Maddox, R. W. Glanville, L. Y. Sakai. 1991. Partial sequence of a candidate gene for the Marfan syndrome. Nature (Lond.). 352:334-337. 